\title{
To Be or Not to Be Governed Like That? Harmful and/or Offensive Advertising Complaints in the United Kingdom's (Self-) Regulatory Context
}

\author{
Kristina Auxtova ${ }^{1} \cdot$ Mary Brennan $^{2} \cdot$ Stephen Dunne ${ }^{2}$
}

Received: 19 August 2019 / Accepted: 11 March 2020 / Published online: 18 March 2020

(c) The Author(s) 2020

\begin{abstract}
This paper demonstrates how the UK's Advertising Standards Authority (ASA) governs advertising ethics with and on behalf of its members and stakeholders. Drawing on an archive of 310 non-commercial (i.e., not-for-profit and public) adjudication reports, we highlight the substantive norms and procedural mechanisms through which the ASA governs advertising complaints alleging offence and/or harm. Substantively, the ASA precludes potential normative transgressions by publishing, disseminating, consulting upon, and updating detailed codes of advertising conduct. Procedurally, the ASA adjudicates between allegations and justifications of offence and harm on a received complaint-by-complaint basis, often upon consequentialist grounds. Such consequentialism, we claim, has the effect of normalizing power imbalances between the ASA's members, on the one hand, and wider stakeholders, on the other hand. The paper argues that, in the context of UK advertising, what Michel Foucault called the right 'to be or not to be governed like that' is enjoyed by relatively few subjects. Having demonstrated how UK advertising practices are governed, the paper closes with suggestions as to how they might be governed otherwise.
\end{abstract}

Keywords Advertising ethics · Advertising regulation · Offensiveness and harmfulness

\section{Introduction}

Recent debates about how and/or whether specific advertising media should be regulated, although important in their own right (e.g.ASA 2017a; see also Auletta 2018; Biddle 2018; Fuchs 2017; Hirschman and Thompson 1997; Kerr et al. 2012; Zuboff 2019), cannot be bracketed off from longer established debates about how and/or whether advertising

Electronic supplementary material The online version of this article (https://doi.org/10.1007/s10551-020-04480-x) contains supplementary material, which is available to authorized users.

Kristina Auxtova

kauxtova001@dundee.ac.uk

Mary Brennan

mary.brennan@ed.ac.uk

Stephen Dunne

stephen.dunne@ed.ac.uk

1 University of Dundee School of Business, 1-3 Perth Road, Dundee DD1 4HN, UK

2 University of Edinburgh Business School, 29 Buccleuch Place, Edinburgh EH8 9JS, UK itself causes harm (Ewen 1976; Goldman and Papson 1996; Hall 2001; Higgins and Tadajewski 2002; Klein 2005; Lasn 1999; Packard 1957; Pollay 1986; Samuel 2013; Schudson 2013; Tadajewski 2006; Treise et al. 1994; Williamson 1978). This paper scrutinizes the norms and processes through which allegedly harmful and/or offensive advertising is regulated and governed in the UK. It does this by analyzing six years of evidence drawn from the non-commercial sector. ${ }^{1}$ By routinely playing the risks of private offences off against the rewards of positive public outcomes (Jones and van Putten 2008; Parry et al. 2013; see also Charry et al. 2014; Pratt and James 1994; West and Sargeant 2004), the non-commercial sector provides particularly compelling insights into the systems of governance over which the UK's Advertising Standards Authority (ASA) presides. It stands to reason that given the absence of the profit motive, the

\footnotetext{
${ }^{1}$ We adopt the ASA's own usage of the term 'non-commercial' to designate the wider not-for-profit and public sectors. Per the archive obtained, the ASA's categorization of 'non-commercial' advertisers includes charities, governmental and non-governmental organizations, community, religious, and political organizations, trade associations, and pressure groups.
} 
non-commercial sector foregrounds ethical considerations that are not reducible to the profit motive (Burt and Mansell 2019).

Although the relative effectiveness of differing models of advertising regulation has been studied in detail (e.g., Boddewyn 1992; Dacko and Hart 2005; Feenstra and González Esteban 2019; Ginosar 2011; Harker 1998; Jones et al. 2008; Muela-Molina and Perelló-Oliver 2014; Preston 1983), little is known about how advertising content is regulated. Even when regulatory and advisory bodies develop prescriptive codes of conduct, allegations of the transgression of stated, implied, or perceived normative standards concerning harm and/or offence persist (Boddewyn 1985; Harker and Harker 2000). Furthermore, while the tactics, themes, and/or products most likely to trigger offences have been well documented (e.g., Chan et al. 2007; Dahl et al. 2003; Fam et al. 2009; Fam and Waller 2003; Waller 2005), and while the groups most likely to register offence have been considered (e.g., Crosier and Erdogan 2001; Harker and Harker 2002; Moyer 1984; Volkov et al. 2002a, 2002b, 2005; Zetterqvist et al. 2015), stakeholders' own descriptions of harms they suffered and/or offences they experienced have received much less attention (on which see Beard 2008a, 2008b; S. Jones and van Putten 2008; Lawson 1985). This may stem from the prevalent consumer focus found across marketing research, with stakeholder marketing emerging to challenge this dominant perspective (Bhattacharya and Korschun 2008; Freeman et al. 2010; Hillebrand et al. 2015; Laczniak and Murphy 2012; Smith et al. 2010). In the spirit of stakeholder marketing, our research allows an insight into the stakeholders' own descriptions, albeit mediated by the governance of the complaint process which produces the archive analyzed (as will be explained further below).

Expanding on Beard (2008a), we emphasize the interplay between complainants, advertisers, and regulators, throughout the duration of the complaint procedure. Through an examination of the ASA's policies and practices, we provide a detailed example of the norms and processes through which allegations of offensiveness and harmfulness in noncommercial advertising are (self-) regulated. The transition from norms to processes entails a transition from principles to procedures. What becomes noteworthy in this regard are the procedures through which decisions are made within situations where the prevalent codes preserve a level of ambiguity that is generally accepted by the affected parties. The complaints handled by the ASA which are not clearly covered by their published and ever evolving norms activate such procedures. While these cases necessarily lend themselves to much more by way of interpretation than the normative formalism through which the majority of complained about cases are settled, they are far from indiscernible. We will claim, on the basis of an empirical analysis of the archival representation of the extra-normative procedures through which these complaints are addressed, that these procedures themselves normalize the distribution of power away from complainants, towards advertisers and regulators.

Our analysis is inspired by the work of Michel Foucault, particularly his insistence that, if critical work is to amount to anything, it must take the task of describing power's manifestation at least as seriously as the task of proposing alternatives (see Lorenzini 2016; Butler 2008). Conceptual and methodological comparisons have been made between Foucault's analyses of power with those undertaken by the sociologists Max Weber and Norbert Elias, particularly concerning whether the detailed analysis of power lends itself to evidence-led interventions (see e.g., McKinlay et al. 2012; Lemke 2007; Dolan 2010; Smith 1999). Power here is variously shown to be dispersed between individuals, rather than it being something held by individuals and so it seems to be for the analyst of social relationships-critical or otherwise-to illustrate the principles through which power manifests, coalesces, and disperses. The Humean question as to whether the description of how power is dispersed between actors entitles us to make claims as to how it should be dispersed between actors persists. The specificity of the Foucauldian approach is to keep this question open while emphasizing the important role played by discourses in the constitution and evolution of power imbalances. We do not deny that extra-discursive phenomena might explain why this is the case, beyond what we have provided here by way of empirical analysis. Following Foucault, however, we have sought to make our claims on the basis of the evidence provided by the discourse we studied and, so with it, the procedures we have shown it to have normalized.

The paper is structured as follows. We begin by reviewing how the ethical and practical challenges of regulating offensive and harmful advertising have been understood. We then discuss the specificities of advertising in the non-commercial sector, which is the context of our study. Next, we indicate how these ethical and practical challenges have been addressed in the UK context, drawing particular attention to the ASA's governance norms and procedures. This section also specifies the nature, extent, and significance of the archival materials we have analyzed. Our conceptualization follows, placing particular emphasis upon the interpretive resources we have drawn from Michel Foucault's work on power and its relationship to discourse, in general, and Carla Willig's (2013) representation of it, in particular. The methodology section then specifies how the evidence was analyzed, by detailing our deployment of Carla Willig's (2013) neo-Foucauldian framework. Our analysis is organized into three sections, respectively emphasizing how the archive we have analyzed (1) produces subject positions (the statementmaker, the debate-participant, and the judgment-passer), (2) normalizes practices (the causing of harm/offence and the 
disempowerment of the harmed/offended) and (3) represents how subjective practices are experienced. By demonstrating how UK advertising practices are governed, the paper closes with suggestions as to how they might be governed otherwise.

\section{Literature, Context, and Conceptualization}

\section{Regulating Offensive and Harmful Advertising}

There is little terminological consistency across the considerable volume of academic literature that has been devoted to the topic(s) of offensive and harmful advertising. While clear definitions elude the ASA as well, we work with their terminology of harm and offence (ASA 2012) since it is on the basis of these that it must be held or hold its subject matter to account. Neither offence nor harm is directly defined in the advertising codes, though their elicitors are detailed (CAP 2017, 2018). For public perception research purposes, the ASA defines offence as "anger or upset caused by something perceived to be insulting, unfair or morally wrong" (ASA 2012, p. 19); no definition of harm is to be found. These definitions, and lack thereof, as we will see, have provoked much disagreement between affected actors, hence emphasizing the importance of looking beyond the norms and into the processes. Attitudinal and behavioral evidence also falls far short of consensus while socio-demographic, psychographic, and situational factors are known to play a significant role in mediating observed outcomes. Specifically, women, older generations, those more educated, and highly religious groups are found to be more offended (e.g., Barnes and Dotson 1990; Chan et al. 2007; Fam and Waller 2003; Phau and Prendergast 2001), as are more conservative cultures (Chan et al. 2007; Fam and Waller 2003). The vocal minority that is likely to complain tends to be described as well-educated, well-off, older, with bohemian tendencies and generally more resources, both intrinsic and extrinsic (Crosier and Erdogan 2001; Volkov et al. 2005).

Conceptual, empirical, characterological, and sociocontextual complications notwithstanding, discrete events in which advertisements are held to have offended imply situations in which elevated cognitive processing levelsspecifically, observed levels of attention, recall, recognition, and retention processes - have been triggered by any given advertisement's having violated (some of) the personal, societal, cultural, religious, and/or moral norms and standards of (some of) its recipients (e.g., Dahl et al. 2003; de Run et al. 2010; Huhmann and Mott-Stenerson 2008; Pope et al. 2004; Veer and Rank 2012). Any given advertisement, for its part, is held capable of triggering offence whenever it promotes products, services, or issues ('matter') which are themselves held to be offensive (Barnes and
Dotson 1990; Fam and Waller 2003), when its manner of execution offends (Barnes and Dotson 1990), and/or when the media through which it is disseminated offend (Phau and Prendergast 2001). While the manner of execution is found to be a more likely cause for offence than offensive matter (e.g., Beard 2008a; Fam et al. 2008; Prendergast et al. 2002; Waller et al. 2008), as are advertisements delivered via push, rather than pull, media (Beard 2008a), congruency between execution and product is argued to contribute to the acceptability of a given advertisement (Christy and Haley 2008; Fam and Waller 2003). However, very little existing research is based on actual offence or harm caused (Beard 2008a).

That any given advertisement potentially can cause offence and/or actually has caused offence is not widely accepted as an ethical aberration in itself, however. In the case of controversial offerings (Fam et al. 2009), shock appeals (Dahl et al. 2003), sexist messaging (Huhmann and Limbu 2016), violent imagery (Coyne et al. 2016), and humor (Beard 2008b; Förster and Brantner 2016), the fact and/or the possibility of offence's manifestation often gets assessed alongside additional factors. Non-commercial advertising seems to require a context-specific moral calculus of its own. While non-commercial advertisements regularly provoke, shock, offend, and even disgust within their audiences (Dahl et al. 2003; Pope et al. 2004), often deliberately, it has been claimed that their doing so is tolerated (Parry et al. 2013) and perhaps even endorsed (S. Jones and van Putten 2008), because of the ends in play.

National and international regulatory bodies have established means of governing controversial advertising practices. For Boddewyn (1992), analyses of advertising ethics should turn away from individualized illustrations of persons and their proportional influences, towards institutionalized illustrations of how principles and protocols are combined towards (self-) regulatory ends. While each regulatory system mediates long-established debates concerning the grounds upon which industrial self-regulation might or might not be justified within particular contexts and/or in itself (Boltanski and Thévenot 2006; Bowen 2019; Carter et al. 2017; Dacko and Hart 2005; Hastings et al. 2010; S. Jones et al. 2008; Locke 1994; Scott 2008; Suchman 1995), Boddewyn's signal achievement is to emphasize the norms and procedures through which advertising has been regulated (see also Boddewyn 1983; Dacko and Hart 2005). He identifies three recurring systems of governance:

(1) a laissez-faire system, characterized by the principle of self-discipline, competitor control and consumer retaliation

(2) a statutory regulatory system, characterized by mandated governmental rules and legal penalties 
(3) a self-regulatory system, characterized by principles of voluntary control mandated and administered by the advertising industry itself.

Various deregulatory movements have given rise to selfregulation, a system adopted by many countries, including the UK (Boddewyn 1985). Despite criticisms about its marking of its own homework (Bowen 2019), lack of transparency and effective judicial tools, limited inclusion of consumers in the processes, and antitrust, self-regulation is perceived as more suitable for dealing with subjective issues of offence, taste, decency, or opinion, thus often reaching beyond minimal legal prescriptions (Boddewyn 1992). It also aims to work in both the industry's and public's interest in that it does not require a proof of injury (Boddewyn 1992). Such subjective issues are difficult to regulate by law (Boddewyn 1985; Harker and Harker 2000) and even when such codes exist, they remain ambiguous (Harker and Harker 2000). Notwithstanding, no existing research attempts to investigate how such system is operationalized to regulate offence and harm-based complaints.

Multiple stakeholders are affected by how offensive and harmful advertising is regulated as such, by whether the specificities of the non-commercial context permit exceptions to these rules, and by the manner in which such exceptions materialize, evolve, and/or dissipate. From this perspective, we should appreciate the regulatory prudence in not defining the norms of harmful and offensive advertising once and for all and in not prohibiting extra-regulatory representations of harmful and offensive advertising from regulatory processes. From this perspective, we can also begin to appreciate the regulatory prudence in making the procedures through which harmful and offensive advertisements are governed themselves clear, consistent, and transparent. From this regulatory prudence appreciating perspective, critical questions nevertheless can and will be asked.

The ethics of harmful and offensive advertising, we will claim, cannot be meaningfully abstracted from the principles and procedures governing the systems of advertising regulation that are in play within any given time and place. Following Boddewyn's example, we will turn our attention away from questions about whether harmful and offensive advertising should be regulated, towards considerations of how harmful and offensive advertising has been regulated.

Internationally, the work of two organizations has been crucial in this regard: the International Chamber of Commerce (ICC), established in 1919 by a group of entrepreneurs calling themselves 'merchants of peace' (ICC 2019), and the European Advertising Standards Alliance (EASA), founded in 1992 by a conglomeration of national self-regulatory organizations (EASA 2019). Both of these organizations' codes of practice have been applied in legal rulings and have facilitated the composition of regulatory policies and infrastructures within late-adopting jurisdictions. In 2016, the International Council on Ad Self-regulation (ICAS) was founded in order to support the sharing of best practice across jurisdictions and in order to facilitate the creation of regulatory infrastructures within emerging markets (ICAS 2018).

Spatial and temporal specificities also abound. In the USA, for example, consumer protection against unfair, deceptive, or fraudulent practices in the marketplace is the primary concern of the Bureau of Consumer Protection, one of three bureaus forming the Federal Trade Commission created in 1914 (Federal Trade Commission 2014). By contrast, the Ukraine's first Advertising Act was not introduced until 1992 (Wolburg and Venger 2009), the Slovak Advertising Standards Council (Rada pre reklamu) was founded in 1995 with the first advertising law passing in 1996 (Rada pre reklamu 2019) and the Advertising Self-Regulation Council in Peru (Consejo Nacional de Autorregulación Publicitaria) was established in 1998 (Gronemeyer 2014).

Formal advertising regulation in the UK began in the 1920s, with the self-regulatory body in existence today, the ASA, founded in 1962 (Nevett 1982). We will consider the specificity of the UK context throughout what follows, both because ours is the first study of it of its kind and because the UK system has regularly been treated as exemplary (Boddewyn 1992; Feenstra and González Esteban 2019; Nevett and Miracle 1986; Petty 1997). What follows is a brief section discussing the specificities of non-commercial advertising, followed by a section elucidating the norms and procedures through which harmful and offensive advertising in the UK has been regulated.

\section{Non-commercial Advertising}

The non-commercial advertising research field is predominantly focused on questions around message framing (e.g., Bennett and Kottasz 2001; Brunel and Nelson 2000; Chang, 2014; Chang and Lee 2009, 2010; Das et al. 2008; Laufer et al. 2010), use of imagery (e.g., Burt and Strongman 2004; Nunn 2004; Small and Verrochi 2009), and responses by various donor and non-donor audiences (e.g., Brunel and Nelson 2000; Chang and Lee 2011; Nelson et al. 2006). No consensus has been reached in terms of positive or negative framing (Das et al. 2008), though emotional imagery, and in particular sad faces and victim portrayals, have been found to trigger sadness and empathy and also increase donation likelihood among the audiences (Bennett and Kottasz 2000; Small and Verrochi 2009). Despite this, specific negative emotions are rarely studied in the non-commercial context (but see Rossiter and Thornton (2004) on fear in antispeeding ads, or Albouy (2017) and Cockrill and Parsonage (2016) on shocking charity advertising). 
Within the context of marketization of the non-commercial sector (Bruce and Chew 2011; Eikenberry and Kluver 2004), it is believed that shocking and offensive advertising tactics are increasingly used by non-profit and public organizations in order to facilitate behavioral change and entice charitable donations (Dahl et al. 2003; Parry et al. 2013; West and Sargeant 2004). Such tactics have been particularly applied to road safety campaigns, anti-smoking campaigns, or charity campaigns fundraising for medical research and better lives for children. Indeed, $62 \%$ of complaints triggered by non-commercial advertising in the UK is due to offence and/or harm (calculation based on the complaints received in the period of our archive (2009-2015)). Many of such campaigns have faced public and academic scrutiny over the ethicality of using such themes as non-commercial organizations are often regarded as inherently moral and thus the use of ethically questionable practices can be seen as incongruent with their ethos (Carter et al. 2017; Hastings et al. 2004; Jones and van Putten 2008).

\section{Regulatory Norms and Complaints Procedures: The Case of the ASA}

The UK's contemporary system of advertising regulation is comprised of three bodies: the Committee of Advertising Practice (CAP), the ASA, and the Advertising Standards Board of Finance (ASBOF). CAP is responsible for writing the advertising codes, ASA supervises and enforces the CAP codes, and ASBOF collects a levy to finance the work of industrial self-regulation. Since 2010, each of these have had equivalents within the broadcast advertising (TV and radio) context: BCAP, ASA (Broadcast), and BASBOF, respectively. The ASA tasks itself with ensuring all UK advertisements are legal, decent, honest, and truthful (ASA 2019a) by monitoring ads for CAP code compliance, dealing with complaints received from consumers and businesses, and conducting public opinion research.

Broadcasters themselves are held responsible by the ASA for withdrawing, rescheduling, and/or changing non-compliant advertisements. Non-broadcast non-compliance can trigger the ASA and/or CAP to circulate advice to withhold advertising space, to withdraw trading privileges, to impose compulsory pre-vetting procedures, to name code-breakers on a publicly available list, and/or to remove already paid for online advertising (ASA 2019b). Code non-compliant advertisements are also disqualified from industry award competitions. Persistent breaches may be referred by the ASA onto the CAP, the Trading Standards Authorities and/or Ofcom (the UK's Communication Regulator) (ASA 2019b). Despite its lack of formal power to either penalize or sanction code transgressions, the vast majority (ASA 2019b) of advertisers abide by the ASA's own code and rulings.
Both the CAP and BCAP Advertising Codes deal explicitly with harm and offence (Sect. 4, see Online Appendix) though advertising matter is excluded from these where offensive products cannot themselves breach the codes. Allegation of distastefulness alone also cannot provide sufficient grounds for a breach of the code. Code compliance is therefore adjudicated solely at the level of advertising execution (CAP 2018). The BCAP Code also includes a section which prohibits advertisements for charities from misrepresenting their organization, cause, or activities and benefits; from suggesting apathy and/or irresponsibility on the part of non-donors; from disrespecting those it seeks to help; and from addressing fundraising messages to children (CAP 2017). In order to minimize allegations of code noncompliance, the CAP offers copy advice while Clearcast and Radiocentre provide clearance services.

Such codes remain ambiguous, both about what constitutes harm and/or offence, and about what might justifiably ground any complainant's recognition and/or experience of harm and/or offence. The assertion that "[a]dvertisements must not be harmful or offensive" (BCAP Code (CAP 2017, p. 24), for example, is accompanied by the assertion that "[a]dvertisements must take account of generally accepted standards to minimise the risk of causing harm or serious or widespread offence" (ibid). The logically requisite definitions of 'serious' and/or 'widespread' offence are not codified (see also Harker and Harker 2000). Similarly, the assertion that " $[\mathrm{m}]$ arketing communications must not cause fear or distress without justifiable reason; if it can be justified, the fear or distress should not be excessive" (CAP Code (CAP 2018 , p. 26) codifies neither what 'justifiable' nor 'excessive' means.

Despite such ambiguities, the ASA presents itself as "a one-stop shop for advertising complaints" (ASA 2019a). In this, they recognize the requirement for the supplementation of the norms over which they preside with a transparent process. The prevalent compliance codes enable the ASA to deem that around $80 \%$ of the complaints it receives do not require investigation (ASA 2019c). The remaining 20\% of complaints undergo either an informal or a formal investigation. Such investigations take anywhere between a few days to almost six months. The informal process usually consists of collaboration and guidance. The formal process, by contrast, requires the participation of advertisers, advertising agencies, the media that published or broadcast the advertisement, and the relevant clearance centers (ASA 2019c). In such instances, the presiding ASA Council assesses noncompliant advertisements against the rules and in light of the responses, evidence, and justifications provided by each of the named parties. In order to come to a ruling, the ASA reserves the right to seek independent expert advice and non-binding industry advice from the CAP's Industry Advisory Panel, its Promotional Marketing and Direct Response 


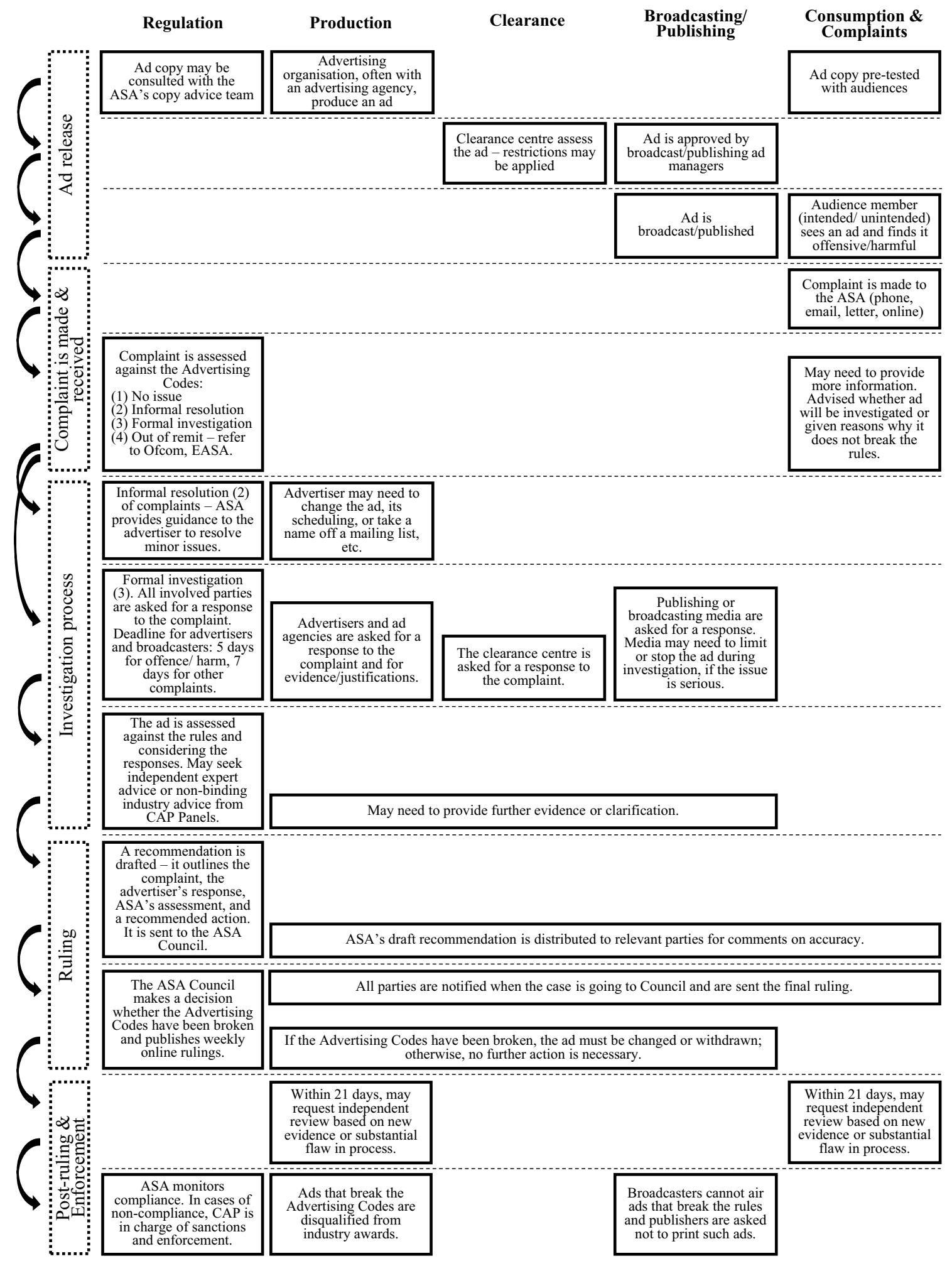

Fig. 1 Stakeholder group involvement in the journey of an ad in the complaint process (UK) (compiled from ASA 2019a, c) 
Panel, and its Online Publications Media Panel. The procedures through which the ASA handles the complaints it receives are detailed in Fig. 1.

The ASA deems over $97 \%$ of published advertisements to have complied with their codes (ASA 2018a). In 2018, it resolved 33,727 complaints against 25,259 cases and facilitated 27,014 own-initiative compliance cases. This resulted in 500 formal rulings and 10,850 ads being amended or withdrawn (ASA 2019d). 98\% of the complaints it received were made by members of the public (ASA 2019d) and, while misleading advertisements accounted for the majority of these (73\%), the most complained about advertisements are generally held to have been offensive (ASA 2018b). In contrast, in the non-commercial sector, offensive and harmful complaints account for $62 \%$ (calculated across the period studied).

Despite such detailed norms and procedures, UK advertising regulation presents the following known problems of (self-)governance:

- the CAP code is written, and partially presided over, by industry representatives (ASA 2019a)

- the industry's self-regulatory body is funded by the very industry that it regulates (ASA 2019a; Nevett and Miracle 1986)

- the independent Council members and the Independent Reviewer are appointed not by external bodies but by the ASA's own Chairman (ASA 2018a, 2019a; Paraskeva 2017)

- the functions of the ASA and the CAP are not clearly separated, either by location or by role (ASA 2017b; Paraskeva 2017)

- the lack of guidance available to the ASA Executive (Paraskeva 2017) and lack of transparency concerning their appointment.

Despite stated intentions towards improved governance, and the ASA's ongoing endeavors to make the presiding limits of its regulatory norms and procedures transparent both to itself and to its stakeholders, unintended problems remain, particularly with respect to structural power imbalances, as we will demonstrate through a detailed examination of how complaints about harmful and offensive non-commercial advertising have been handled. Paraskeva's (2017) independent audit considers how advertising practitioners might govern themselves otherwise for the sake of the industry. Our analysis takes this criticism further by considering how advertising practitioners might govern themselves for the sake of the industry and its wider stakeholders.

\section{Conceptualization}

It would be naïve to treat the materials we gather as adequate manifestations of the norms, processes, and outcomes we have sought to investigate. It would be presumptuous to read our suspicions about what is really going on too far into these. This challenge of "walking the tightrope" (1996, p. 143), as Rosalind Gill calls it, between a literal and a mystical deployment of a nominated framework-in the case of this study a Foucauldian framework-seems inseparable from the experience of trying to say something about language, with language, in the way of the discourse analyst. As Louise Vingoe (2007, p. 74-75) puts it:

Many authors have expressed concern over the feasibility of accurately describing or articulating the analytic procedure followed in discourse analytic studies... Despite such pessimism, numerous authors have attempted to develop procedural guidelines for the analysis of discourse. Examples from Discursive Psychology include Potter and Wetherell (1987) and Billig (1997) and, from Foucauldian Discourse Analysis, Kendall and Wickham (1999), Parker (1992), and Willig (2001).

Initially drawing upon Willig (2001) in her attempt to develop a framework through which the analysis of the relationship between discourse and power could be conceived along specifically Foucauldian lines, Vingoe's work itself became a foundation upon which Willig (2013, p. 141) built her subsequent iteration of applied discourse analytic Foucauldianism. While the ASA's complaint norms and procedures seem a world away from the medical and psychiatric formations often analyzed by neo-Foucauldians, as well as by Foucault himself $(2003,2009)$, they are nevertheless of a piece in their expressed sensitivity to the inseparability of power and discourse. Foucault does not attribute the fragments of knowledge held within juridical archives, within medical manuals, and/or within institutional procedures, to dispassionate feats of the detached will. "Something is produced", he writes, "because the instincts meet, fight one another, and at the end of their battles finally reach a compromise. That something is knowledge" (Foucault 1996, see also Lemke 2002; Patton 2018). Nietzsche's historiographical refusal to separate logos and pathos inspired Foucault's methodological protocols (see Foucault 1977), they inspired the neo-Foucauldian analysis of the relationship between discourse and power, and they will inform our analysis of how the ASA's complaints procedures normalize power imbalances.

In specifying the nature of his intellectual debt to Nietzsche in particular, Foucault insists that genealogical analysis is "gray, meticulous and patiently documentary" (1977, p. 139). It is the collection and thematization of just 
so many documents, rulebooks, and modes of ritualization. It requires analysts to treat their empirical material not as passive receptacles of information but as the very context within which power relations can be shown to manifest. The Foucauldian Discourse Analyst must therefore first gather and subsequently organize specific documentary instances into a framework. They do not treat conflicting passions and interests as by-products of archival records, nor do they prioritize the suspicion that the true nature of these passions and interests are logically detectable but empirically unavailable. The Foucauldian Discourse Analyst analyses power's discursive manifestations themselves. Discourse, within such studies, does not conceal the true nature of power relations, it is rather understood to be constitutive of the context within which power relations manifest. So it will be through the analysis of the outcomes of disputes themselves, of the norms through which these were considered, and of the procedures through which these decisions were arrived at in cases of recognizably elevated controversy that we will demonstrate the role played by power relations in the processing of complaints about advertising.

Foucault's ever evolving reflections upon, and revisions of, his own historical procedures (e.g., Davidson 1994; Foucault 1985, 1998) impress upon us the need to distinguish between research methodology, as it often gets written about by social scientists, and method, in the way that scholars in the humanities have described and understood it (e.g., Arribas-Ayllon and Walkerdine 2017; Bastalich 2009; Buchanan 2008; Buchanan et al. 2017; Dixon 2007; C. Jones 2003a; Kendall and Wickham 1999; Raffnsøe et al. 2016; Scheurich and McKenzie 2008). Martin Heidegger-the philosopher about whom Foucault wrote nothing yet read much (Foucault 1982; see also Dreyfus 2008; Sluga 2005)— often writes of method in the Ancient Greek sense of path, route and/or passage: the way in which the speaker/writer got to the claims that they ended up making (e.g., Heidegger 1998). We will proceed to specify how we walked Gill's tightrope between a literal and a mystical representation of Foucauldian Discourse Analysis below, aided considerably by Willig (2013), once we have said more about the object towards which we will proceed along it.

\section{Methodology}

\section{Data Set}

We obtained an archive of 310 individual adjudication reports from the ASA, produced in response to 9,055 individual complaints concerning harmfulness and/or offensiveness in non-commercial advertising during the period analyzed (October 2009 and September 2015). Of these 310 reports:
- 73 are lengthier 'published' formal investigations. These include descriptions of the advertisements themselves, summaries of complaints, advertiser justifications, and regulatory assessments.

- 237 are brief 'unpublished' informal investigations. These do not include advertiser's justifications.

Both of these report types have the same structure and the same purpose of documenting the complaint going through the investigative process and as such are analyzable in the same way. While the unpublished reports do not include the advertisers' justifications and are often briefer, they enrich our understanding of the complainants' and regulator's discourses as well as of the process itself.

In terms of issues of complaint:

- $161(52 \%)$ allege offence.

- 65 (21\%) allege harm.

- $84(27 \%)$ allege both offence and harm.

\section{Approach}

Following the instructive examples of others who have imitated some of Foucault's modes of archival interpretation within and throughout their own archival interpretations (e.g., Agamben 1999, 2009; Hoskin 1994; Jacques 1996; McKinlay 2006; McKinlay and Pezet 2010; Snoek 2010), we have adapted some of his - and their-concepts and heuristics to all of our purposes. We initiated this process by questioning who influences the content of the ASA's adjudication reports. van Dijk's analysis of 'discourse access profiles' (1993) encourages the initial determination of whether particular actors dominate the archive and so we mimicked his suggested means of doing so within the context of our own investigation. This was done by exploring the stakeholders' involvement in the journey of a complaint through the investigative process (Fig. 1) as well as by exploring the length of discourse allowed to, and provided by, each stakeholder group studied.

Following this provisional analysis of the discourse access profiles in play within and throughout the archive, we then analyzed its adjudication reports following the incrementally developmental neo-Foucauldian framework proposed by Willig (2013), already mentioned above. Six stages of analysis were performed, in keeping with her instructions:

(1) identifying the discursive constructions of objects;

(2) locating these discursive constructions within wider discourses;

(3) examining the functions of these constructions;

(4) identifying the subject positions produced by these constructions; 
Table 1 Discourse access profiles by length of discourse

\begin{tabular}{|c|c|c|c|c|c|c|c|}
\hline & \multicolumn{3}{|c|}{$\begin{array}{l}\text { Published reports }(i=73) \text { (formal investi- } \\
\text { gations) }\end{array}$} & \multicolumn{2}{|c|}{$\begin{array}{l}\text { Unpublished reports } \\
(n=237) \text { (informal } \\
\text { investigations) }^{c}\end{array}$} & \multicolumn{2}{|l|}{ Total } \\
\hline & Pages $^{\mathrm{a}}$ & Words & Average $(\%)^{\mathrm{b}}$ & Pages & Words & Pages & Words \\
\hline Complainants & 8.5 & 4,257 & 9.0 & 30.5 & 14,600 & 39 & 18,857 \\
\hline Advertisers & 32.5 & 23,399 & 49.6 & 1 & 473 & 33.5 & 23,872 \\
\hline Regulator & 31 & 19,541 & 41.4 & 43 & 28,602 & 74 & 48,143 \\
\hline
\end{tabular}

a Page numbers rounded to nearest 0.5

${ }^{\mathrm{b}}$ Indicates average proportion of the discourse allocated to each stakeholder group (calculated based on word counts)

'Unpublished reports generally do not include advertisers' comments
(5) exploring how these subject positions normalize practices;

(6) demonstrating how the experiences of these subject positions are represented

We begin by recognizing advertising complained about for reasons of offence and/or harm as our discourse object and by identifying the various discourse constructions of the object (Stage 1). We then situate the discursive constructions into the broader discursive contexts they belong to (Stage 2). Next, we reflect on the functions of these constructions and identify roles of the stakeholders as represented in the archive (Stage 3). Building on these three stages, we were able to identify various subject positions taken by the complainants (statement-makers), advertisers (debate-participants), and the regulator (judgment-passer) (Stage 4). It could be objected that our recourse to this subject-position terminology, rather than simply naming the actors, seems something of a contrivance. This is an unfortunate but to our mind inevitable feature of operationalizing this particular framework. For Willig, following Foucault, subject positions and actors cannot be treated synonymously since the former denotes a technical term that establishes the foundations for the subsequent analysis whereas the latter implies subjectivity's manifestation beyond the archive. Actors may well exist beyond the archive, but subject positions are produced within discourses. There are significant overlaps between both, but they are not the same: our refusal to conflate the two, while aesthetically unappealing, is based upon methodological and conceptual grounds.

An inductive and iterative open coding process was followed to develop the discourse constructions, which were then grouped into themes based on the broader discourses and subject positions they represent. Building on this understanding of the subject positions and their discourses, we looked deeper and exposed the relationship between the discourses available and the institutional practices in place (Stage 5), hence questioning their legitimation and the power structures within (Willig 2013). We conclude the analysis by considering issues of subjectivity, delimiting the feelings, thoughts, and experiences represented within the subject positions identified (Stage 6). With the latter two stages, this framework allows us to progress from an understanding of the stakeholders' subject positions to raising critical questions about the regulatory practices in place and thus returning to the discussion of the self-regulatory system.

The results of our operationalization of this framework are presented and explained in the following section. We first present our analysis of discourse access profiles. Then, a taxonomical summary of the outcomes of Stages One through Four is presented in Tables 2, 3, and 4 under the heading of 'the production of subjects'. The normalization of practices through which harm and/or offence manifest, and of the disempowerment of the harmed and/ or offended - that is to say the outcomes of Stage Fiveare discussed in the following section's third sub-section. Stage Six, 'the representation of experiences', emphasizes how the experience of harmful and/or offensive advertising is represented not by its subjects themselves but both to and about them by others. This matter is discussed in the next section's final sub-section.

\section{Analysis and Findings}

\section{Discourse Access Profiles}

Our analysis finds that the archive is disproportionately dominated by pronouncements made by advertisers and the regulator (Table 1). This analysis further supports what was already becoming visible in Fig. 1-the lack of voice, or access to participation in the debate, the complainants are allowed.

Complaints are represented briefly and structured in accordance with the sections of the compliance codes that the ASA's representatives have deemed relevant. Once a complaint has been registered, complainants may be asked 


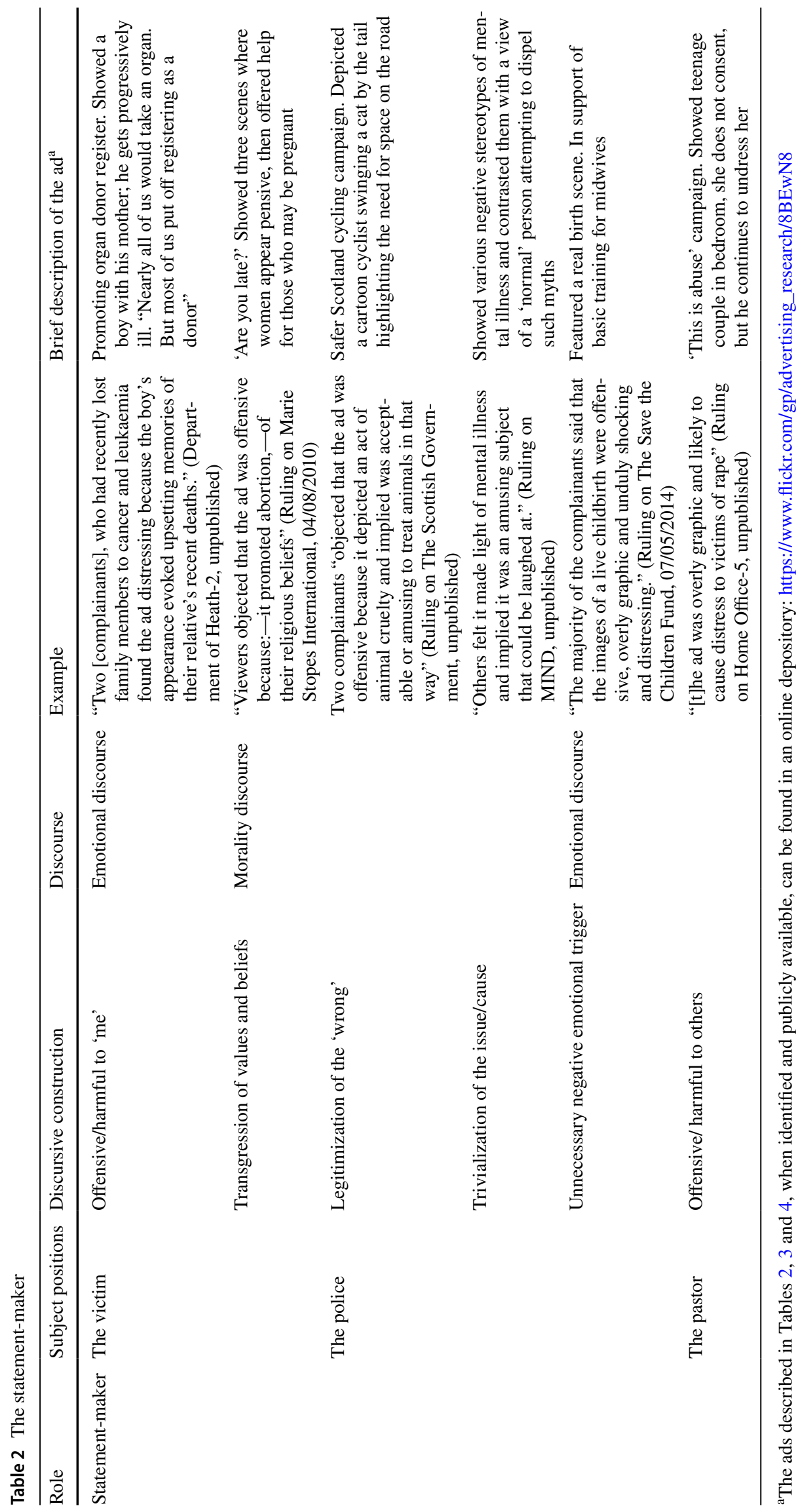




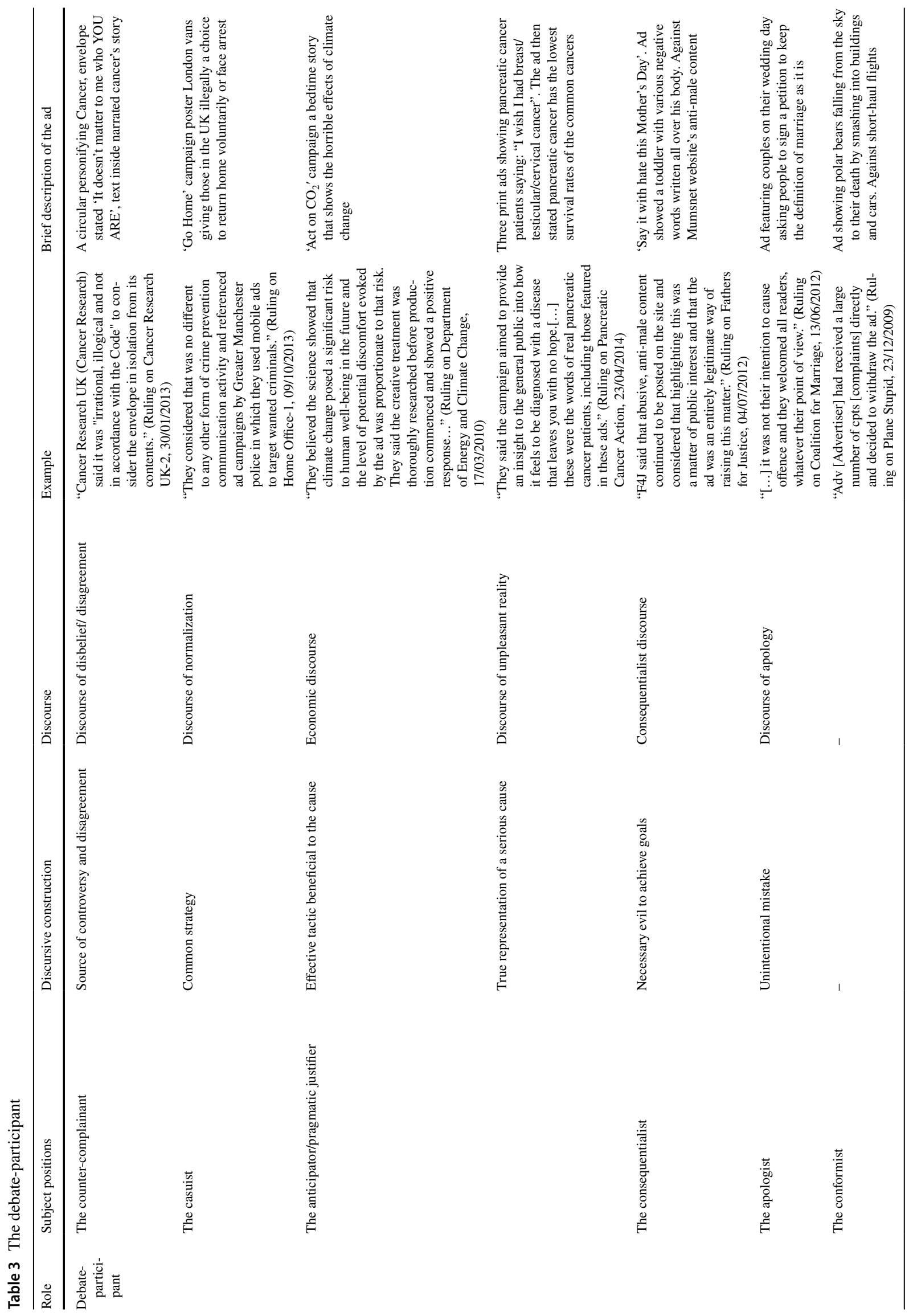




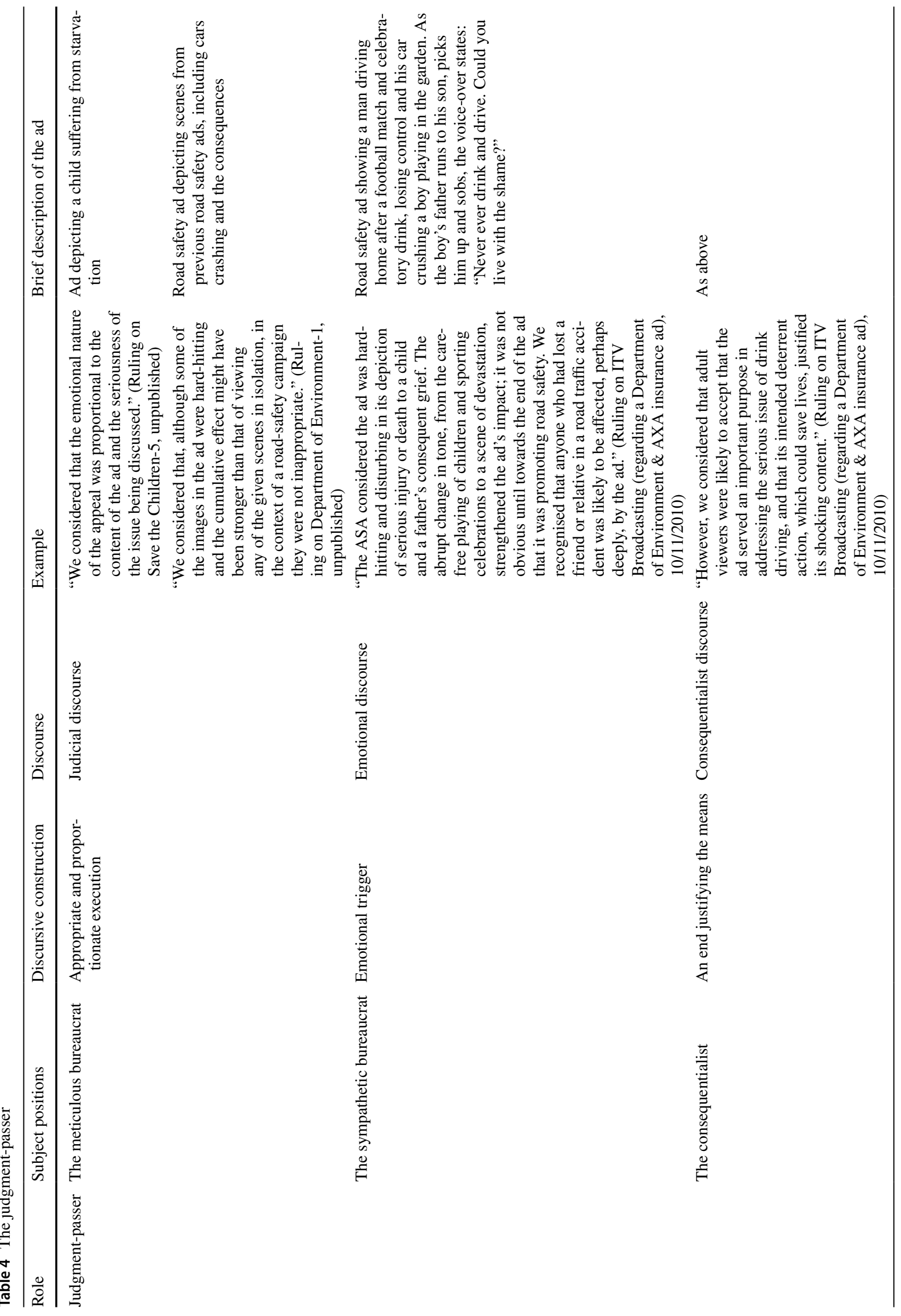


for clarification. They are not entitled to develop their complaint or the grounds upon which it is made although they are informed about its progression. Advertisers, by contrast, are entitled to not only register their responses to the complaints received against them but also to develop detailed justifications as to why, despite the complaint(s) of their having caused offence, their behavior should be deemed legitimate and as such should be warranted. In more complex investigations, statements from ad agencies, broadcasters, and clearance centers are also included. The regulator, for its part, permits itself both the right to decide and, so with it, the right to decide upon the extent of the space required for judgmental corroborations.

\section{The Production of Subjects}

Stage One of Willig's framework requires us to identify noncommercial advertisements that were complained about for their offensiveness or potential harm as our object. The 310 adjudication reports concerning this object contain various explicit and implicit constructions of 'offensive' and 'harmful' advertising. Such complained about advertisements are variously represented as an unnecessary emotional trigger, a transgression of audience values, a tactic deployed effectively, and/or a tactic that is justifiable in the light of the cause.

In Stage Two, we consider how these interpretations of offensive and harmful advertising became connected to wider discussions of emotions, of morality, of economics, of judiciary, of consequentialism, and of normalization.

Stage Three consists of our identification of what functions the archive enabled and/or disabled on the part of its formally acknowledged stakeholders. ${ }^{2}$ The regulator is the primary author of the archive and, as such, it subordinates the positions taken by complainants, as well as the arguments and evidence provided by advertisers, into a narrative that it must grant itself the final say upon. It does this by establishing that there are contradictory views in play, between which it must arbitrate, and in so doing it grounds both the specificity and the necessity of its own governing authority. These adjudication reports draw upon multiple sources: the advertisement itself, the prevalent advertising

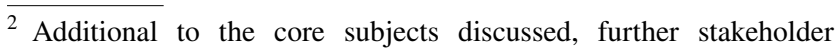
groups, namely the media (broadcasters/publishers) (19 cases), clearance centers (3), ad agencies (2), and other related organizations (3), occasionally provided statements in the archive, adopting one of the subject positions available to the debate-participants. Predominantly supporting the advertisers $(n=17 ; 63 \%)$, they provided their own justifications or repeated those of the advertisers. Two partner organizations and one publisher distanced themselves from the final execution of the ad and others focused on scheduling issues, clearance restrictions, and errors rather than the discourse object.
} 
codes, the submitted complaint forms, the evidence provided by the advertiser and other bodies, and occasionally expert advice. Stylistically, they rely heavily upon indirect and/or recorded speech. Representations of the positions held by the complainant and the advertiser thereby take the form of plot devices in as much as they prefigure the dramaturgy of decision conventionally enacted by the genre of reported adjudication. Therein, we find that the offended complainant functions as a maker of statements, the offending advertiser functions as a participant within debates and the mediating regulator functions as the one who both can and must pass judgment.

Stage Four operationalizes a distinction between stakeholders (complainants, advertisers, and regulators) and subject positions (statement-makers, debate-participants, and judgment-passers) in order to populate the taxonomy of enunciative repertoires represented within Table 3. In so doing, it demonstrates the importance of differentiating between the interests represented by persons, on the one hand, and the manner in which these interests become normalized as subject positions, on the other.

As has already been established, the judgment-passer casts the triggering of the statement-maker by the debateparticipant as the catalyst for the investigative procedure that any adjudication report must simultaneously represent and conclude. Expressions of the inner-experience of having been offended and/or harmed must therefore become translated into the language of the compliance code. Consequentially, little consideration is given to how or why these statements were made. What matters in the context of any particular juridical procedure's self-presentation, instead, is that complaints have been translated into alleged statement(s) of (non-) compliance that might or might not become judged to have been compelling.

The archive suggests three recurring statement-making subject positions: the victim, the police, and the pastor (see Table 2). Victims refer to their personal experiences, background, and/or closeness to the issue and/or cause as the basis upon which the complained about advertisement is claimed to have caused offence and/or harm. Police claim that the complained about advertisement goes against their values and beliefs, that it legitimizes irresponsible behaviors, that it trivializes the issue and/or cause, and/or that it unnecessarily triggers negative emotions. Pastors express an abiding concern for the well-being of children and other vulnerable groups that are either represented in or might be affected by the complained about advertisement.

The archive also suggests a spectrum of debate-participating subject positions (Table 3). At one extreme, we find the counter-complainant, who either argues against the grounds upon which the complaint was made and/or against the motives of the statement-maker. On the other extreme we find the apologist who, rather than succumbing to guilt, apologizes for the harm and/or offence its actions have caused, with the important caveat that they neither anticipated nor intended these. In between these extremes we position the casuist, who debates the specificities of its case with respect to named antecedents, the anticipator, who argues the justifiability of its case by means of testimonials gathered from would-be complainants, the pragmatic justifier, who rationalizes their choice by the issue's difficult reality or the tactic's economic effectiveness, and the consequentialist, who defends their advertisement's causing of harm and/or offence as an evil lesser to that of not raising awareness. Conformists, for their part, elect not to activate their juridical right of reply and remove the complained about advertisement.

The final set of subject positions the archive suggests are the judgment-passer's own. Before considering what the archive suggests in this regard, the remarkable play of self-relationship and self-production warrants our acknowledgment. Not only does the judgment-passer take the position of the author, both of every adjudication report as well as of all of the rules governing each adjudication report, the judgment-passer also authorizes itself to determine how each subject of the process of adjudication is to be represented. Not only does the judgment-passer write the processes and the outcomes of its adjudications into being, it also writes itself into being as that which must be permitted to take positions with respect to itself.

Four interrelated modes of self-production are to be discerned from the archive in this regard (Table 4). Firstly, the judgment-passer casts itself as a meticulous bureaucrat that must administer its own rules in order to produce authoritative decisions. Of the 310 reports we analyzed, only $49(16 \%)$ were upheld in full $(41 ; 13 \%)$ or in part $(8 ; 3 \%)$. The bureaucratic function, properly executed, is such that it takes no position on whether such outcomes are desirable. The frequent recourse to modalities, such as 'likely', 'would', or 'we believe', however, suggests a level of resolve that is often less than unwavering (e.g., "We believed that viewers were likely to understand that the brief ads would be unable to include full details about the progression and treatment of the disease." (Ruling on Cancer Research UK-9, unpublished). The judgment-passer's bureaucratic rationality therefore needs not inculcate itself from moral sentiment, since it is also often given to sympathetic bureaucrats to pass what they claim to know to be difficult judgments. In the final two subject positions the judgment-passer grants to itself, we find mirror images of two that it had already granted to the debate-participant and the statement-maker, namely, the consequentialism of the former and the policing function of the latter. The next two sections perform our articulation of each of the final two stages of Willig's framework. 
Fig. 2 The statement-makers' experienced and anticipated emotions. The numbers in this diagram represent the instances of each emotion found within the summaries of complaints in the archive. The emotions are presented as interpreted and reported by the ASA

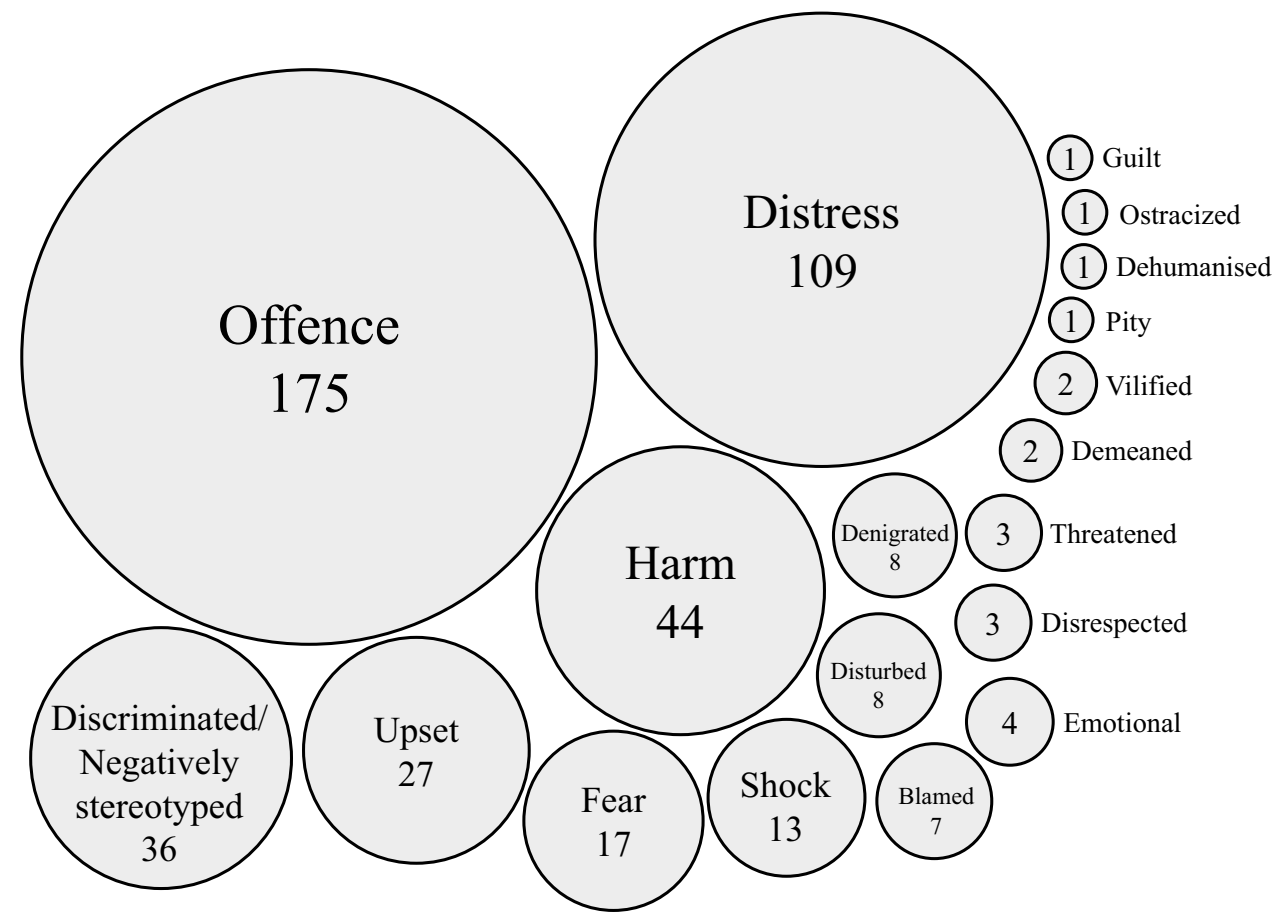

\section{The Normalization of Practices}

Stage Five considers how the range of the practices available to the statement-maker, the debate-participant, and the judgment-passer are represented within, and throughout, the archive. Whereas Stages One to Four enabled us to demonstrate how the governance situation produces subject positions, Stage Five considers what these various subject positions are enabled to do about harmful and/ or offensive advertising, by the norms and procedures over which the ASA presides. Willig (2013, p. 141) proposes two central questions under this heading:

- What possibilities for action are mapped out by these constructions?

- What can be said and done from within these subject positions?

Our analysis leads us to identify two corresponding answers. To the first question, our general response is that the discourse of harm and/or offence we have studied normalizes harmful and offensive advertisements. This has the effect of (a) normalizing how statements about harm and offence can be made, (b) normalizing how the participation in debates about harm and offence is to be conducted (c) normalizing how judgments about whether harm and offence is warranted are formed. To the second question, our general response is that the capacity of statement-makers to represent their cases is constrained relative to the rights of debate-participants to argue their case and the rights of judgment-makers to settle any case. Stage Five therefore suggests a governance situation in which harmful and/or offensive advertisements might be experienced as unfortunate but must be recognized as unavoidable, allocating rights to act on a diminishing basis to differing parties.

Statement-makers regularly mentioned the distress, upset, or fear (see Fig. 2) which particular advertisements can or have provoked, e.g., "The majority of the complainants said that the images of a live childbirth were offensive, overly graphic and unduly shocking and distressing" (Ruling on The Save the Children Fund, 07/05/2014) or "Eleven cpns [complainants], who felt the ad was scaremongering, objected that the ad was offensive and could cause unnecessary distress" (Ruling on Motor Neurone Disease Association-2, unpublished). These are represented, by the judgment-passer, as instances of harmfulness and/or offensiveness in and of themselves, ethical wrongs which do not and perhaps even cannot figure within any reparative practices, apologetic rituals not least of all. The practice of making a statement about harm and/ or offence is represented within the archive as one of registering a complaint with the authorities. The practice of passing a judgment about these complaints, by contrast, is represented as a rational re-composition of mere opinion.

In Aristotelian terms, the true virtues of the regulator must be assessed as expressions not of episteme but of phronesis (Aristotle n.d.[1998], n.d.[1999]). The practical wisdom of the judgment-passer is such that it knows which norms to apply to complaints about harmful and/or offensive advertising by doing the very work of application 
on a case-by-case basis. Moreover, it also grants itself privileged knowledge about how audiences are affected by advertisements in the passing of judgments concerning such matters, e.g., "We considered that viewers were likely to appreciate that the emotive scenes depicted in the ad were proportionate to the danger that careless driving presents" (Ruling on Department of the Environment-8, unpublished) or "we considered that most viewers were likely to interpret the ad as light-hearted rather than as being sexist or objectifying men" (Ruling on MyBuilder, unpublished). That the judgment-passer considers the ASA Executive recommendations and debate-participant justifications in advance of passing judgment only serves to further normalize the constraints upon the range of practices available to the statement-maker.

It is the consequentialism regularly deployed by the judgment-passer, a consequentialism that it often shared with the debate-participant, which enables it to translate any statement about harm and/or offence as such into a practical requirement for the application of means/ends calculus. The judgment-passer presented by the archive, by itself, is certainly no Kantian. Nor, indeed, do deontological ethics feature prominently whenever advertising industry representatives gather to recognize and celebrate its exemplars. Having researched advertiser websites, advertising catalogues (e.g., adforum.com, adage.com, coloribus.com, campaign.com, adsoftheworld.com), creative agency websites, the records of the Institute of Practitioners of Advertising, as well as YouTube, and Google, we find that at least 30 of the campaigns about which the judgment-passer adjudicated won at least one advertising industry award, and some won several. That the ends justify the means presents itself to debate-participants and judgment-passers not as a moral theory but as a practical mantra. Statement-makers may argue otherwise but they are denied the practical means of self-expression within the presiding governance structures.

\section{The Representation of Experiences}

The final stage of the analytic process considers the relationship between discourse and subjectivity. It strives to describe how subjective experience is represented throughout the archive by identifying "what can be felt, thought and experienced from within the various subject positions" identified (Willig 2013, p.133). We present the outcomes of this stage in summary form below, on a subject-position by subject-position basis, by means of an illustrative example.

Statement-makers are given frequent recourse to subjective experience in the form of feelings and emotions. It is they who believe they have been harmed and/or offended and, as such, it is they who express themselves by way of distress, fear, shock, upset, guilt, and even blame. The statement-maker's emotions are represented by the archive as a matter of a private experience, publicly stated. Personal similarities and differences are represented as just so many variations on this basic theme. This is not to say that the archive conceals the diversity of experiences that it represents: this point is best illustrated by means of example. Over 100 complaints were lodged against a campaign in which a wish to have a different kind of cancer was stated by representations of pancreatic cancer patients. Pancreatic cancer has the lowest survival rates of all common cancers and the campaign sought to provoke audience attention to this fact. Statement-makers found the campaign offensive and distressing, regularly claiming that the will to have another form of cancer undermined how serious it was to be afflicted by that cancer despite its more favorable survival rate. Some of these statement-markers were themselves cancer patients and/or close to cancer patients and so their testimonies were often as disturbingly provocative as they were profoundly personal.

The debate-participant, while acknowledging the difficulty of the situation, nevertheless justified the campaign upon pragmatic grounds. The wish for another type of cancer is, they claimed, commonly experienced by pancreatic cancer patients and the campaign simply aimed to bring this difficult fact to light. It appears that the negative responses to the campaign were anticipated by the debate-participant, and that the risk of causing such harm and/or offence was calculated to have been worth taking. Subjective experience intervenes here not to the detriment of the juridical process but as an enabling factor.

While the judgment-passer expressed considerable sympathy with statement-makers, and with their underpinning sincerity, these were set off against the context within which the allegedly harmful and/or offensive statements were themselves made. By focusing on the execution of the campaign itself, the judgment arrived at was that, interpreted appropriately - that is to say in the spirit in which it was expressed-serious or widespread offence or unjustifiable distress were not caused. To wade through testimonials to terminal illness and yet rule against them is to prioritize some consequences above others. The archive makes no secret of the fact that such work is not easily done but that it can get done.

So the consequentialist and the sympathetic bureaucrat are represented as human subjects-that is as not just procedural subjects - inasmuch as they too experience innerturmoil and personal conflict. Nevertheless, right judgment and institutional prerogative ultimately prevail. To trigger negative emotions, such subjects are represented to believe, is both unfortunate and defensible. The counter-complainant, for its part, engages in these complaint procedures while having its experience of harm and offence very narrowly circumscribed for it. Consequentialism justifies the allegedly harmful and/or offensive practices of the debate-participant 
before, during, and after the complaints' procedure. It absolves the judgment-passer of any guilt and responsibility they might feel for the harms and/or offences caused by that which they have chosen to authorize. To make justifiable decisions is to be a particular kind of subject.

\section{Summary and Recommendations}

Alongside the obligation to comply with prevailing legal requirements, professional codes of conduct specify what normative grounds professional practices should be expressed in terms of and assessed against (Zayer and Coleman 2015). Although not opposed to the ends to which such codes of conduct have been put, or even to the means by which they have been developed - at least not in principleBusiness Ethicists have raised important questions about the extent to which, perhaps paradoxically, professional codes of conduct might serve to constrain ethical agency, by serving as an alibi for ethical controversy (Aasland 2004; Baker and Roberts 2011; C. Jones 2003b; Karamali 2007; Kelemen and Peltonen 2001; Roberts 2001; ten Bos 1998; ten Bos and Willmott 2001). In the case of the ASA, we have observed a situation within which normative codes of compliance are complemented by formal procedures stipulating how, in cases of controversy, the rightness or wrongness of any given situation will be judged (see also Carter et al. 2017). That the ASA governs complaints about harmful and/ or offensive advertising through a combination of norms and procedures might go some way towards explaining why it has been widely and regularly commended. Whilst our study draws on a non-commercial sector archive, these norms and procedures govern the regulation of all UK advertising and the key stakeholders examined are interested in, impacted by, and/or involved with both commercial and non-commercial advertising. Our study also has relevance to analyses of advertising regulation beyond the UK context, both in terms of the conceptual resources we deploy as well as the empirical findings we illustrate.

This paper has not undermined the ASA's governance norms and processes. Rather, it has analyzed how these have been put into practice in cases where complaints against harmful and/or offensive non-commercial advertising have been made. By operationalizing concepts and frameworks inspired by the work of Michel Foucault, our analysis has demonstrated how the very norms and procedures through which harmful and/or offensive advertising is contested and (self-) regulated produces docile subjects, normalizes controversial practices, and de-individualizes subjective experiences. As illustrated in our analysis, the manner in which the ASA passes judgments on the nature and consequences of harmful and offensive advertising, we have shown, disempowers complainants, relative to other stakeholders, by reducing their role to the voicing of mere complainants. We do not claim to have revealed concealed intentions in any of this. Rather, we have demonstrated how the governance situation itself both mobilizes and normalizes experiences (Stage 6), practices (Stage 5), and subjects (Stages $1-4)$. This is not to rule conspiratorial intentions or events out from the situation in principle. It is only to separate its hypothetical explanations from the actual processes of governmentality that this paper has analyzed (see Bjerg and Presskorn-Thygesen 2017).

UK advertising audiences need not be governed like that. While it is not for us as researchers to judge whether they should or should not be governed like that, it is clear that complainants could be elevated from their status as makers of statements to that of participants in debates, a subject position that already exists in the governance situation yet is presently denied to them. And this regovernance of subjects could be quite easily achieved along the following lines. Firstly, by granting greater levels of involvement to complainants and the wider public throughout the regulatory and investigative process. Ability to provide support for their complaints and counterargue the advertisers' justifications is the minimum required. To include advertising's stakeholders, including organizations such as 'The Citizens Advice Bureau' and 'Which?' throughout the complaint adjudication process would be to imitate aspects of the models of representation and governance already presided over by the Human Rights Committee (International Justice Resource Centre 2019).

Secondly, by including complainants and the wider public in the process of clarifying the normative principles and codes of conduct, not only in their application but also within their formulation and throughout their revision. The inputs of wider stakeholders are already involved in the ongoing formulation of ASA policy in the form of audience research exploring prevailing standards in society (e.g., research on public perceptions of harm and offence in UK advertising (ASA 2012)) as well as wider stakeholder-focused research (e.g., research into gender stereotypes in advertising (ASA 2018a, b)). However, inclusion of complainants and specifically targeted public groups that are most likely affected by the studied advertising issue in such research could further strengthen these efforts. Furthermore, the expertise of the Charity Commission and the National Council for Voluntary Organisations are proposed to be included in new Sector Panels (ASA 2019e). Why not also include such external stakeholders in the processes of clarifying the principles by which offensive and/or harmful advertisements are recognized?

Acknowledgements This work was supported by the ESRC under Grant \#1486352, and the University of Edinburgh College of Arts, 
Humanities and Social Sciences. An earlier version of this manuscript forms part of the first author's doctoral thesis. Early findings have also been presented at the AMA Marketing \& Public Policy Conference and the AMS World Marketing Congress.

Funding This study was funded by the ESRC under Grant \#1486352 and the University of Edinburgh College of Arts, Humanities and Social Sciences.

\section{Complice with Ethical Standards}

Conflict of interest The first author received funding from the ESRC and the University of Edinburgh for her doctoral training of which this work is a part.

Open Access This article is licensed under a Creative Commons Attribution 4.0 International License, which permits use, sharing, adaptation, distribution and reproduction in any medium or format, as long as you give appropriate credit to the original author(s) and the source, provide a link to the Creative Commons licence, and indicate if changes were made. The images or other third party material in this article are included in the article's Creative Commons licence, unless indicated otherwise in a credit line to the material. If material is not included in the article's Creative Commons licence and your intended use is not permitted by statutory regulation or exceeds the permitted use, you will need to obtain permission directly from the copyright holder. To view a copy of this licence, visit http://creativecommons.org/licenses/by/4.0/.

\section{References}

Aasland, D. G. (2004). On the ethics behind "business ethics". Journal of Business Ethics, 53(1), 3-8.

Agamben, G. (1999). Remnants of Auschwitz: The witness and the archive. New York: Zone Books.

Agamben, G. (2009). The signature of all things: On method. New York: Zone Books.

Albouy, J. (2017). Emotions and prosocial behaviours: A study of the effectiveness of shocking charity campaigns. Recherche et Applications En Marketing, 32(2), 4-25.

Aristotle. (n.d.[1998]). Politics. (C. D. C. Reeve, Ed.\&Trans.). Indianapolis: Hackett Publishing.

Aristotle. (n.d.[1999]). Nicomachean ethics. (T. Irwin, Ed.\&Trans.). Indianapolis: Hackett Publishing.

Arribas-Ayllon, M., \& Walkerdine, V. (2017). Foucauldian discourse analysis. In C. Willig \& W. Stainton-Rogers (Eds.), The Sage handbook of qualitative research in psychology (pp. 106-124). London: SAGE.

ASA. (2012). Public perceptions of harm and offence in UK advertising. London: Advertising Standards Authority.

ASA. (2017a). Showing more impact: Advertising Standards Authority Committees of Advertising Practice Annual Report 2017. London: ASA \& CAP.

ASA. (2017b). ASA response to Dame Janet Paraskeva's independent audit of the ASA's performance against its Commitment to Good Regulation. London: Advertising Standards Authority.

ASA. (2018a). ASA response to Dame Janet Paraskeva's recommendation for a review of other independent review and appeal processes to identify good practice. London: Advertising Standards Authority.

ASA. (2018b). Top 10 most complained about ads from 2017. ASA news (01/02/2018). https://www.asa.org.uk/news/top-10-mostcomplained-about-ads-from-2017.html. Accessed 3 March 2019.
ASA. (2019a). ASA: About ASA and CAP. ASA and CAP official website. https://www.asa.org.uk/about-asa-and-cap.html. Accessed 3 March 2019.

ASA. (2019b). Sanctions. ASA and CAP official website. https:// www.asa.org.uk/codes-and-rulings/sanctions.html. Accessed 3 March 2019.

ASA. (2019c). ASA: How we handle complaints. ASA and CAP official website. https://www.asa.org.uk/about-asa-and-cap/the-work-wedo/how-we-handle-complaints.html. Accessed 3 March 2019.

ASA. (2019d). More impact online: Advertising Standards Authority Committees of Advertising Practice Annual Report 2018. London: ASA \& CAP.

ASA. (2019e). The Industry Panels that help the ASA and CAP in their regulatory decision making. ASA and CAP Official Website. https://www.asa.org.uk/news/the-industry-panels-thathelp-the-asa-and-cap-in-their-regulatory-decision-makin g.html. Accessed 1 March 2019.

Auletta, K. (2018). How the math men overthrew the mad men. The New Yorker (21/05/2018). https://www.newyorker.com/news/ annals-of-communications/how-the-math-men-overthrew-themad-men. Accessed 5 August 2019.

Baker, M., \& Roberts, J. (2011). All in the mind? Ethical identity and the allure of corporate responsibility. Journal of Business Ethics, 101(1), 5-15.

Barnes, J. H., \& Dotson, M. J. (1990). An exploratory investigation into the nature of offensive television advertising. Journal of Advertising, 19(3), 61-69.

Bastalich, W. (2009). Reading Foucault: Genealogy and social science research methodology and ethics. Sociological Research Online, 14(2-3), 1-10.

Beard, F. K. (2008). How products and advertising offend consumers. Journal of Advertising Research, 48(1), 13-21.

Beard, F. K. (2008). Advertising and audience offense: The role of intentional humor. Journal of Marketing Communications, 14(1), 1-17.

Bennett, R., \& Kottasz, R. (2000). Emergency fund-raising for disaster relief. Disaster Prevention and Management, 9(5), 352-360.

Bennett, R., \& Kottasz, R. (2001). Promotional message strategies for disability charities' employment services. International Journal of Nonprofit \& Voluntary Sector Marketing, 6(1), 21.

Bhattacharya, C. B., \& Korschun, D. (2008). Stakeholder marketing: Beyond the four Ps and the customer. Journal of Public Policy and Marketing, 27(1), 113-116.

Biddle, S. (2018). Facebook uses artificial intelligence to predict your future actions for advertisers, says confidential document. The Intercept (13/04/2018). https://theintercept.com/2018/04/13/ facebook-advertising-data-artificial-intelligence-ai/. Accessed 5 August 2019.

Billig, M. (1997). Rhetorical and discursive analysis: How families talk about the royal family. In N. Hayes (Ed.), Doing Qualitative Analysis in Psychology. Hove: Psychology Press.

Bjerg, O., \& Presskorn-Thygesen, T. (2017). Conspiracy theory: Truth claim or language game? Theory, Culture and Society, 34(1), 137-159.

Boddewyn, J. J. (1983). Outside participation in advertising selfregulation: The case of the advertising standards authority (UK). Journal of Consumer Policy, 6(1), 77-93.

Boddewyn, J. J. (1985). Advertising self-regulation: Private government and agent of public policy. Journal of Public Policy \& Marketing, 4, 129-141.

Boddewyn, J. J. (1992). Global perspectives on advertising selfregulation: Principles and practices in thirty-eight countries. Wesport, CT: Greenwood Publishing Group.

Boltanski, L., \& Thévenot, L. (2006). On justification: Economies of worth. Princeton: Princeton University Press. 
Bowen, F. (2019). Marking their own homework: The pragmatic and moral legitimacy of industry self-regulation. Journal of Business Ethics, 156(1), 257-272.

Bruce, I., \& Chew, C. (2011). Debate: The marketization of the voluntary sector. Public Money \& Management, 31(3), 155-157.

Brunel, F. F., \& Nelson, M. R. (2000). Explaining gendered responses to "help-self" and "help-others" charity ad appeals: The mediating role of world-views. Journal of Advertising, $29(3), 15-28$.

Buchanan, J. (2008). Using Foucaldian critical discourse analysis as a methodology in marketing. In Australia and New Zealand Marketing Academy Conference 2008 (pp. 67-88). Sydney.

Buchanan, J., Jones, M. L., \& Tann, K. (2017). An analysis of media representation of the Australian electronic gaming machine industry. Journal of Gambling Issues, 36, 65-96.

Burt, C. D., \& Strongman, K. (2004). Use of images in charity advertising: Improving donations and compliance rates. International Journal of Organisational Behaviour, 8(8), 571-580.

Burt, E., \& Mansell, S. (2019). Moral agency in charities and business corporations: Exploring the constraints of law and regulation. Journal of Business Ethics, 159(1), 59-73.

Butler, N. (2008). Critical and clinical management studies. Ephemera, $8(1), 7-25$.

CAP. (2017). The BCAP code: The UK code of broadcast advertising (1st ed.). London: The CAP.

CAP. (2018). The CAP code: The UK code of non-broadcast advertising and direct \& promotional marketing (12th ed.). London: The CAP.

Carter, S. M., Mayes, C., Eagle, L., \& Dahl, S. (2017). A code of ethics for social marketing? Bridging procedural ethics and ethics-inpractice. Journal of Nonprofit \& Public Sector Marketing, 29(1), 20-38.

Chan, K., Li, L., Diehl, S., \& Terlutter, R. (2007). Consumers' response to offensive advertising: A cross-cultural study. International Marketing Review, 24(5), 606-628.

Chang, C. (2014). Guilt regulation: The relative effects of altruistic versus egoistic appeals for charity advertising. Journal of Advertising, 43(3), 211-227.

Chang, C.-T., \& Lee, Y.-K. (2009). Framing charity advertising: Influences of message framing, image valence, and temporal framing on a charitable appeal. Journal of Applied Social Psychology, 39(12), 2910-2935.

Chang, C.-T., \& Lee, Y.-K. (2010). Effects of message framing, vividness congruency and statistical framing on responses to charity advertising. International Journal of Advertising, 29(2), 195-220.

Chang, C. T., \& Lee, Y. K. (2011). The "I" of the beholder: How gender differences and self-referencing influence charity advertising. International Journal of Advertising, 30(3), 447-478.

Charry, K., De Pelsmacker, P., \& Pecheux, C. L. L. (2014). How does perceived effectiveness affect adults' ethical acceptance of anti-obesity threat appeals to children? When the going gets tough, the audience gets going. Journal of Business Ethics, 124(2), 243-257.

Christy, T. P., \& Haley, E. (2008). The influence of advertising context on perceptions of offense. Journal of Marketing Communications, 14(4), 271-291.

Cockrill, A., \& Parsonage, I. (2016). Shocking people into action: Does it still work? An empirical analysis of emotional appeals in charity advertising. Journal of Advertising Research, 56(4), 401-413.

Coyne, S. M., Callister, M. A., Gentile, D. A., \& Howard, E. (2016). Media violence and judgments of offensiveness: A quantitative and qualitative analysis. Psychology of Popular Media Culture., 54, 372-389.
Crosier, K., \& Erdogan, B. Z. (2001). Advertising complainants: Who and where are they? Journal of Marketing Communications, 7(2), 109-120.

Dacko, S. G., \& Hart, M. (2005). Critically examining theory and practice: Implications for coregulation and coregulating broadcast advertising in the United Kingdom. International Journal on Media Management, 7(1\&2), 2-15.

Dahl, D. W., Frankenberger, K. D., \& Manchanda, R. V. (2003). Does it pay to shock? Reactions to shocking and nonshocking advertising content among university students. Journal of Advertising Research, 43(3), 268-280.

Das, E., Kerkhof, P., \& Kuiper, J. (2008). Improving the effectiveness of fundraising messages: The impact of charity goal attainment, message framing, and evidence on persuasion. Journal of Applied Communication Research, 36(2), 161-175.

Davidson, A. I. (1994). Ethics as ascetics: Foucault, the history of ethics, and ancient thought. In G. Gutting (Ed.), The Cambridge companion to foucault (pp. 115-140). Cambridge: Cambridge University Press.

de Run, E. C., Muhammad Mohsin, B., Fam, K.-S., \& Hui Yin, J. (2010). Attitudes towards offensive advertising: Malaysian Muslims' views. Journal of Islamic Marketing, 1(1), 25-36.

Dixon, M. A. (2007). Transforming power: Expanding the inheritance of Michel Foucault in organizational studies. Management Communication Quarterly, 20(3), 283-296.

Dolan, P. (2010). Space, time and the constitution of subjectivity: Comparing Elias and Foucault. Foucault Studies, 8, 8-27.

Dreyfus, H. L. (2008). Being and power: Heidegger and foucault. International Journal of Philosophical Studies, 4(1), 1-16.

EASA. (2019). European Advertising Standards Alliance. https://www. easa-alliance.org/about-easa. Accessed 4 July 2019.

Eikenberry, A. M., \& Kluver, J. D. (2004). The marketization of the nonprofit sector: Civil society at risk? Public Administration Review, 64(2), 132-140.

Ewen, S. (1976). Captains of consciousness: Advertising and the social roots of the consumer culture. New York: McGraw-Hill.

Fam, K.-S., \& Waller, D. S. (2003). Advertising controversial products in the Asia Pacific: What makes them offensive? Journal of Business Ethics, 48(3), 237-250.

Fam, K.-S., Waller, D. S., \& Yang, Z. (2009). Addressing the advertising of controversial products in China: An empirical approach. Journal of Business Ethics, 88(1), 43-58.

Fam, K.-S., Waller, D. S., Ong, F.-S., \& Yang, Z. (2008). Controversial product advertising in China: Perceptions of three generational cohorts. Journal of Consumer Behaviour, 7, 461-469.

Federal Trade Commission. (2014). Federal trade commission: Our history. https://www.ftc.gov/about-ftc/our-history. Accessed 15 November 2018.

Feenstra, R. A., \& González Esteban, E. (2019). Autocontrol: A critical study of achievements and challenges in the pursuit of ethical advertising through an advertising self-regulation system. Journal of Business Ethics, 154(2), 341-354.

Förster, K., \& Brantner, C. (2016). Masking the offense? An ethical view on humor in advertising. Journal of Mass Media Ethics, 31(3), 146-161.

Foucault, M. (1977). Nietzsche, genealogy, history. In D. F. Bouchard (Ed.), Language, counter-memory, practice: Selected essays and interviews by Michel Foucault (pp. 139-164). Ithaca: Cornell Univeristy Press.

Foucault, M. (1982). Truth, power, self: An interview with Michel Foucault-October 25th, 1982. In L. H. Martin, H. Gutman, \& P. H. Hutton (Eds.), Technologies of the self: A seminar with Michel Foucault (pp. 9-15). London: Tavistock.

Foucault, M. (1985). The history of sexuality: The use of pleasure. New York: Pantheon Books. 
Foucault, M. (1996). Truth and juridical forms. Social Identities, 2(3), 327.

Foucault, M. (1998). Aesthetics, method, and epistemology. In JD Faubion (Ed.). New York: New Press.

Foucault, M. (2003). The birth of the clinic: An archaeology of medical perception. London: Routledge.

Foucault, M. (2009). History of madness. London: Routledge.

Freeman, R. E., Harrison, J. S., Wicks, A. C., Parmar, B. L., \& de Colle, S. (2010). Stakeholder theory: The state of the art. Cambridge: Cambridge University Press.

Fuchs, C. (2017). Social media: A critical introduction (2nd ed.). London: SAGE.

Gill, R. (1996). Discourse analysis: Practical implementation. In J. T. E. Richardson (Ed.), Handbook of qualitative research methods for psychology and the social sciences. Leicester: BPS Books.

Ginosar, A. (2011). The regulation of advertising. In D. Levi-Faur (Ed.), Handbook on the politics of regulation (pp. 254-266). Cheltenham: Edward Elgar.

Goldman, R., \& Papson, S. (1996). Sign wars: The cluttered landscape of advertising. New York: Guilford Press.

Gronemeyer, M.-E. (2014). Peru. In M. A. Shaver \& S. An (Eds.), The global advertising regulation handbook (pp. 80-90). London: Routledge.

Hall, S. (2001). Encoding/decoding. In M. Gigi Durham \& D. M. Kellner (Eds.), Media and cultural studies: Keyworks (pp. 138-144). Malden: Blackwell Publishers.

Harker, D. (1998). Achieving acceptable advertising: An analysis of advertising regulation in five countries. International Marketing Review, 15(2), 101-118.

Harker, D., \& Harker, M. (2000). The role of codes of conduct in the advertising self-regulatory framework. Journal of Macromarketing, 20(2), 155-166.

Harker, D., \& Harker, M. (2002). Dealing with complaints about advertising in Australia: The importance of regulatory. International Journal of Advertising, 21(1), 37-41.

Hastings, G., Brooks, O., Stead, M., Anker, T., \& Farrell, T. (2010). Failure of self regulation of UK alcohol advertising. The BMJ, 340, b5650.

Hastings, G., Stead, M., \& Webb, J. (2004). Fear appeals in social marketing: Strategic and ethical reasons for concern. Psychology and Marketing, 21(11), 961-986.

Heidegger, M. (1998). Pathmarks. In: W McNeill (Ed.). Cambridge: Cambridge University Press.

Higgins, M., \& Tadajewski, M. (2002). Anti-corporate protest as consumer spectacle. Management Decision, 40(4), 363-371.

Hillebrand, B., Driessen, P. H., \& Koll, O. (2015). Stakeholder marketing: Theoretical foundations and required capabilities. Journal of the Academy of Marketing Science, 43(4), 411-428.

Hirschman, E. C., \& Thompson, C. J. (1997). Why media matter: Toward a richer understanding of consumers' relationships with advertising and mass media. Journal of Advertising, 26(1), 43-60.

Hoskin, K. (1994). Boxing clever: For, against and beyond Foucault in the battle for accounting theory. Critical Perspectives on Accounting, 5(1), 57-85.

Huhmann, B. A., \& Limbu, Y. B. (2016). Influence of gender stereotypes on advertising offensiveness and attitude toward advertising in general. International Journal of Advertising, 35(5), 846-863.

Huhmann, B. A., \& Mott-Stenerson, B. (2008). Controversial advertisement executions and involvement on elaborative processing and comprehension. Journal of Marketing Communications, 14(4), 293-313.

ICAS. (2018). International council on Ad self-regulation: History. https://icas.global/about/history. Accessed 3 March 2019.
ICC. (2019). International chamber of commerce-history. https://iccwb o.org/about-us/who-we-are/history/. Accessed 4 July 2019.

International Justice Resource Centre. (2019). Human Rights Committee. International Justice Resource Centre Official Website. https ://ijrcenter.org/un-treaty-bodies/human-rights-committee/\#Indiv idual_Complaints. Accessed 23 February 2019.

Jacques, R. (1996). Manufacturing the employee: Management knowledge from the 19th to 21st centuries. London: SAGE.

Jones, C. (2003). Foucault's inheritance/inheriting Foucault. Culture and Organization, 8(3), 225-238.

Jones, C. (2003). As if business ethics were possible, "within such limits". Organization, 10(2), 223-248.

Jones, S., Hall, D., \& Munro, G. (2008). How effective is the revised regulatory code for alcohol advertising in Australia? Drug and Alcohol Review, 27(1), 29-38.

Jones, S., \& van Putten, K. (2008). An analysis of consumer complaints about social marketing advertisements in Australia and New Zealand. Journal of Nonprofit \& Public Sector Marketing, 20(1), 97-117.

Karamali, E. (2007). Has the guest arrived yet? Emmanuel Levinas, a stranger in business ethics. Business Ethics, 16(3), 313-321.

Kelemen, M., \& Peltonen, T. (2001). Ethics, morality and the subject: The contribution of Zygmunt Bauman and Michel Foucault to "postmodern" business ethics. Scandinavian Journal of Management, 17(2), 151-166.

Kendall, G., \& Wickham, G. (1999). Using Foucault's methods. London: Sage.

Kerr, G., Mortimera, K., Dickinson, S., \& Waller, D. S. (2012). Buy, boycott or blog: Exploring online consumer power to share, discuss and distribute controversial advertising messages. European Journal of Marketing, 46(3/4), 387-405.

Klein, N. (2005). No logo. London: HarperCollins.

Laczniak, G. R., \& Murphy, P. E. (2012). Stakeholder theory and marketing: Moving from a firm-centric to a societal perspective. Journal of Public Policy \& Marketing, 31(2), 284-292.

Lasn, K. (1999). Culture jam: How to reverse America's suicidal consumer binge-and why we must. London: HarperCollins.

Laufer, D., Silvera, D. H., McBride, J. B., \& Schertzer, S. M. B. (2010). Communicating charity successes across cultures: Highlighting individual or collective achievement? European Journal of Marketing, 44(9/10), 1322-1333.

Lawson, R. W. (1985). An analysis of complaints about advertising. International Journal of Advertising, 4, 279-295.

Lemke, T. (2002). Foucault, governmentality, and critique. Rethinking Marxism, 14(3), 49-64.

Lemke, T. (2007). An indigestible meal? Foucault, governmentality and state theory. Distinktion, 8(2), 43-64.

Locke, S. (1994). Self-regulation in advertising. Consumer Policy Review, 4(2), 111-116.

Lorenzini, D. (2016). From counter-conduct to critical attitude: Michel Foucault and the art of not being governed quite so much. Foucault Studies, 21, 7-21.

McKinlay, A. (2006). Managing Foucault: Genealogies of management. Management \& Organizational History, 21(6), 486-495.

McKinlay, A., Carter, C., \& Pezet, E. (2012). Governmentality, power and organization. Management \& Organizational History, 7(1), 3-15.

McKinlay, A., \& Pezet, E. (2010). Accounting for Foucault. Critical Perspectives on Accounting, 21(6), 486-495.

Moyer, M. (1984). Characteristics of consumer complainants: Implications for marketing and public policy. Journal of Public Policy \& Marketing, 3, 67-84.

Muela-Molina, C., \& Perelló-Oliver, S. (2014). Advertising self-regulation: A comparative analysis between the United Kingdom and Spain. Communication \& Society, 27(3), 1-18. 
Nelson, M. R., Brunel, F. F., Supphellen, M., \& Manchanda, R. V. (2006). Effects of culture, gender, and moral obligations on responses to charity advertising across masculine and feminine cultures. Journal of Consumer Psychology, 16(1), 45-56.

Nevett, T. R. (1982). Advertising in Britain: A history. London: The History of Advertising Trust.

Nevett, T. R., \& Miracle, G. E. (1986). The British system of advertising self-regulation: An historical perspective. Proceedings of the American Academy of Advertising Conference (pp. R2-R6).

Nunn, H. (2004). Emotional death: the charity advert and photographs of childhood trauma. Journal for Cultural Research, 8(3), 271-292.

Packard, V. (1957). The hidden persuaders. New York: D. McKay Company.

Paraskeva, J. (2017). Independent audit of the ASA's commitment to good regulation. https://www.asa.org.uk/asset/D5EFAE37C7F7-40BA-ABCD89BE86B27FFD/. Accessed 3 March 2019.

Parker, I. (1992). Discourse dynamics: Critical analysis for social and individual psychology. London: Routledge.

Parry, S., Jones, R., Stern, P., \& Robinson, M. (2013). 'Shockvertising': An exploratory investigation into attitudinal variations and emotional reactions to shock advertising. Journal of Consumer Behaviour, 12(2), 112-121.

Patton, P. (2018). Foucault, Nietzsche and the history of truth. In A. Rosenberg \& J. Westfall (Eds.), Foucault and Nietzsche: A critical encounter (pp. 35-58). London: Bloomsbury Academic.

Petty, R. D. (1997). Advertising law in the United States and European Union. Journal of Public Policy and Marketing, 16(1), $2-13$.

Phau, I., \& Prendergast, G. (2001). Offensive advertising: A view from Singapore. Journal of Promotion Management, 7(1/2), 71-90.

Pollay, R. W. (1986). The distorted mirror: Reflections on the unintended consequences of advertising. Journal of Marketing, 50(2), $18-36$.

Pope, N. K. L., Voges, K. E., \& Brown, M. R. (2004). The effect of provocation in the form of mild erotica on attitude to the ad and corporate image: Differences between cause-related and productbased advertising. Journal of Advertising, 33(1), 69-82.

Potter, J., \& Wetherell, M. (1987). Discourse and social psychology: Beyond attitudes and behaviour. London: Sage.

Pratt, C. B., \& James, E. L. (1994). Advertising ethics: A contextual response based on classical ethical theory. Journal of Business Ethics, 13(6), 455-468.

Prendergast, G., Ho, B., \& Phau, I. (2002). A Hong Kong view of offensive advertising. Journal of Marketing Communications, $8(3), 165-177$.

Preston, I. L. (1983). A review of the literature on advertising regulation. Current Issues and Research in Advertising, 6(2), 1-37.

Rada pre reklamu. (2019). About RPR: Rada pre reklamu. https://www. rpr.sk/en/about-rpr. Accessed 18 April 2019

Raffnsøe, S., Gudmand-Høyer, M., \& Thaning, M. S. (2016). Foucault's dispositive: The perspicacity of dispositive analytics in organizational research. Organization, 23(2), 272-298.

Roberts, J. (2001). Corporate governance and the ethics of Narcissus. Business Ethics Quarterly, 11(1), 109-127.

Rossiter, J. R., \& Thornton, J. (2004). Fear-pattern analysis supports the fear-drive model for antispeeding road-safety TV ads. Psychology \& Marketing, 21(11), 945-960.

Samuel, L. R. (2013). Freud on Madison Avenue: Motivation research and subliminal advertising in America. Philadelphia: University of Pennsylvania Press.

Scheurich, J. J., \& McKenzie, K. B. (2008). Foucault's methodologies: Archeology and genealogy. In N. K. Denzin \& Y. S. Lincoln (Eds.), Collecting and interpreting qualitative materials (3rd ed., pp. 313-349). London: SAGE.
Schudson, M. (2013). Advertising, the uneasy persuasion (RLE Advertising): Its dubious impact on American society. London: Routledge.

Scott, W. R. (2008). Institutions and organizations (3rd ed.). Thousand Oaks, CA: Sage.

Sluga, H. (2005). Foucault's encounter with Heidegger and Nietzsche. In G. Gutting (Ed.), The Cambridge companion to Foucault (pp. 210-239). Cambridge: Cambridge University Press.

Small, D. A., \& Verrochi, N. M. (2009). The face of need: Facial emotion expression on charity advertisements. Journal of Marketing Research, 46(December), 777-787.

Smith, D. (1999). The civilizing process and the history of sexuality: Comparing Norbert Elias and Michel Foucault. Theory and Society, 28(1), 79-100.

Smith, N. C., Drumwright, M. E., \& Gentile, M. C. (2010). The new marketing myopia. Journal of Public Policy and Marketing, 29(1), 4-11.

Snoek, A. (2010). Agamben's Foucault: An overview. Foucault Studies, 10, 44-67.

Suchman, M. C. (1995). Managing legitimacy: Strategic and institutional approaches. Academy of Management Review, 20(3), 571-610.

Tadajewski, M. (2006). Remembering motivation research: Toward an alternative genealogy of interpretive consumer research. Marketing Theory, 6(4), 429-466.

ten Bos, R. (1998). Essai: Business ethics and Bauman ethics. Organization Studies, 18(6), 997-1014.

ten Bos, R., \& Willmott, H. (2001). Towards a post-dualistic business ethics: Interweaving reason and emotion in working life. Journal of Management Studies, 38(6), 769-793.

Treise, D., Weigold, M. F., Conna, J., \& Garrison, H. (1994). Ethics in advertising: Ideological correlates of consumer perceptions. Journal of Advertising, 23(3), 59-69.

van Dijk, T. A. (1993). Principles of critical discourse analysis. Discourse \& Society, 4(2), 249-283.

Veer, E., \& Rank, T. (2012). Warning! The following packet contains shocking images: The impact of mortality salience on the effectiveness of graphic cigarette warning labels. Journal of Consumer Behaviour, 11(3), 225-233.

Vingoe, L. M. (2007). A portfolio of stigma, personality disorder and counselling psychology. Unpublished Doctoral Thesis, City University London.

Volkov, M., Harker, D., \& Harker, M. (2002a). Complaint behaviour: A study of the differences between complainants about advertising in Australia and the population at large. Journal of Consumer Marketing, 19(4/5), 319-332.

Volkov, M., Harker, D., \& Harker, M. (2002). Opinions about advertising in Australia: A study of complainants. Journal of Marketing Communications, 8, 229-242.

Volkov, M., Harker, D., \& Harker, M. (2005). Who's complaining? Using MOSAIC to identify the profile of complainants. Marketing Intelligence and Planning, 23(3), 296-312.

Waller, D. S. (2005). A proposed response model for controversial advertising. Journal of Promotion Management, 11(2/3), 3-15.

Waller, D. S., Christy, T. P., \& Fam, K.-S. (2008). Perceptions of offensive advertising elements: A China-U.S. comparison. Journal of East-West Business, 14(3-4), 325-343.

West, D. C., \& Sargeant, A. (2004). Taking risks with advertising: The case of the not-for-profit sector. Journal of Marketing Management, 20(9-10), 1027-1045.

Williamson, J. E. (1978). Decoding advertisements: Ideology and meaning in advertising. London: Marion Boyars.

Willig, C. (2001). Introducing qualitative research in psychology. Adventures in theory and method. Buckingham: Open University Press. 
Willig, C. (2013). Foucauldian discourse analysis. In C. Willig (Ed.), Introducing qualitative research in psychology (3rd ed., pp. 106-124). Maidenhead: McGraw-Hill Education.

Wolburg, J. M., \& Venger, O. (2009). "Regulating sin" across cultures: A comparison of alcohol ads in Ukrainian and American magazines. Journal of Advertising, 38(4), 15-36.

Zayer, L. T., \& Coleman, C. A. (2015). Advertising professionals perceptions of the impact of gender portrayals on men and women: A question of ethics? Journal of Advertising, 44(3), 264-275.

Zetterqvist, A. V., Merlo, J., \& Mulinari, S. (2015). Complaints, complainants, and rulings regarding drug promotion in the United Kingdom and Sweden 2004-2012: A quantitative and qualitative study of pharmaceutical industry self-regulation. PLoS Medicine, 12(2), $1-28$

Zuboff, S. (2019). The age of surveillance capitalism: The fight for a human future at the new frontier of power. London: Profile Books.

Publisher's Note Springer Nature remains neutral with regard to jurisdictional claims in published maps and institutional affiliations. 